\title{
Chemical weathering of new pyroclastic deposits from Mt. Merapi (Java), Indonesia.
}

\begin{abstract}
The Java Island, Indonesia with abundant amount of pyroclastic deposits is located in the very active and dynamic Pacific Ring of Fires. Studying the geochemical weathering indices of these pyroclastic deposits is important to get a clear picture about weathering profiles on deposits resulting from the eruption of Mt. Merapi. Immediately after the first phase of the eruption (March to June 2006), moist and leached pyroclastic deposits were collected. These pyroclastic deposits were found to be composed of volcanic glass, plagioclase feldspar in various proportions, orthopyroxene, clinopyroxene, olivine, amphibole and titanomagnetite. The total elemental composition of the bulk samples (including trace elements and heavy metals) was determined by wet chemical methods and X-ray fluorescence (XRF) analyses. Weathering of the pyroclastic deposits was studied using various weathering indices. The Ruxton ratio, weathering index of Parker, Vought resudual index and chemical index of weathering of moist pyroclastic deposits were lower than those of the leached samples, but the alteration indices (chemical and plagioclase) were slightly higher in the moist compared to the leached pyroclastic deposits.
\end{abstract}

Keyword: Weathering index; Pyroclastic deposit; Andesite; Merapi; Indonesia. 